\title{
Misexpression of Hoxa-13 induces cartilage homeotic transformation and changes cell adhesiveness in chick limb buds
}

\author{
Yuji Yokouchi, ${ }^{1}$ Satoru Nakazato, ${ }^{1}$ Masakazu Yamamoto, ${ }^{1}$ Yoshihiro Goto, ${ }^{1}$ Takashi Kameda, ${ }^{2}$ \\ Hideo Iba, ${ }^{2}$ and Atsushi Kuroiwa ${ }^{1,3}$ \\ ${ }^{1}$ Department of Molecular Biology, School of Science, Nagoya University, Furo-cho, Chikusa-ku, Nagoya, 464-01 Japan; \\ ${ }^{2}$ Department of Gene Regulation, Institute of Medical Science, University of Tokyo, Minato-ku, Tokyo, 108 Japan
}

\begin{abstract}
During chick limb development, the $A b d-B$ subfamily of genes in the HoxA cluster are expressed in a region-specific manner along the proximodistal axis. To elucidate the function of Hoxa-13 that is expressed in the autopod during normal limb development, Нoxa-13 was misexpressed in the entire limb bud with a replication-competent retroviral system. Misexpression of Hoxa-13 resulted in a remarkable size reduction of the zeugopodal cartilages as a result of the arrest of cartilage cell growth and differentiation restricted in the zeugopod. This size reduction seems to be attributable to homeotic transformation of the cartilages in the zeugopod to the more distal cartilage, that of the carpus/tarsus. This transformation was specific to Hoxa-13 and was not observed by overexpression of other Hox genes. These results indicate that Hoxa-13 is responsible for switching the genetic code from long bone formation to short bone formation during normal development. When the limb mesenchymal cells were dissociated and cultured in vitro, Hoxa-13-expressing limb mesenchymal cells reassociated and were sorted out from nonexpressing cells. Forced expression of Hoxa-13 at the stage that endogenous Hoxa-13 was not expressed as of yet altered the homophilic cell adhesive property. These findings indicate the involvement of Hoxa-13 in determining homophilic cell-to-cell adhesiveness that is supposed to be crucial for the cartilage pattern formation.
\end{abstract}

[Key Words: Hox; limb bud; chick; misexpression; retroviral vector; homeotic transformation; cell adhesiveness]

Received June 30, 1995; revised version accepted August 29, 1995.

Morphogenesis of the limb bud is an ideal model for studying the mechanism of pattern formation because the essential processes of most pattern formation in vertebrate development, such as the axial determination, regional control of cell growth, and differentiation, are required in this simple system (for review, see Wolpert 1990; Tabin 1992; Duboule 1994). Localized positional signals were proposed to define the three axes of the limb bud for proper initiation and maintenance during the process of pattern formation. Recently, the molecular nature of these positional signals was elucidated as secreted signal molecules (Niswander et al. 1993; Riddle et al. 1993; Parr and McMahon 1995). These localized positional signals are then transferred to the limb mesenchymal cells and support polarized growth of limb bud with complex cross-regulating circuit (Niswander et al. 1994). On the other hand, these signals support both temporally and spatially sequential establishment of po-

${ }^{3}$ Corresponding author. sition or region-specific positional value in cells of the progress zone.

The primary visible process of limb pattern formation is cartilage morphogenesis after proximodistal progression. The cartilage pattern is formed through two distinctive developmental phases. Initially, the limb mesenchymal cells assemble together and form an aggregate to produce precartilagenous condensation. This precartilage rudiment grows distally by recruitment of the mesenchymal cells at the distal end. In the first phase, the topological pattern of the cartilaginous rudiment is determined along the anteroposterior and proximodistal axes by branching or segmentation bifurcation of the precartilagenous condensation (Oster et al. 1988). In the second phase, namely the growth and differentiation phase, each cartilaginous rudiment develops depending on its position, resulting in specific morphology in each cartilage (Hinchliffe and Johnson 1980). The actual pattern formation process directed by the positional value is assumed to be the local control of cell growth, differentiation, and mobility, as apparently the same precursor 
limb mesenchymal cells produce position-specific morphology of the limb cartilage.

From the results of structural analyses, vertebrate $H O x$ genes are thought to share a common ancestry with Drosophila homeotic genes, which determine regional identity along the anteroposterior axis in developing fly embryo (for review, see McGinnis and Krumlauf 1992; Krumlauf 1994). Hox genes have coordinated expression domains along the anteroposterior body axis during ontogeny. Functional studies to produce loss of function by targeted gene disruption in mice showed that homeotic transformation or dysmorphology resulted within the expression domain (for review, see Krumlauf 1994). Ectopic misexpression of Hox genes to mimic gain of function mutations induced homeotic transformation toward structures anterior to the normal expression domain (e.g., see Balling et al. 1989; Lufkin et al. 1992; Polloc et al. 1992). These observations suggest that Hox gene products function as the regulators that determine regional identity as Drosophila homeotic genes.

During vertebrate limb development, the Hox genes in the $A b d-B$ subfamily of HoxD (Hoxd-11-Hox-13) and HoxA (Hoxa-10, Hoxa-11, and Hoxa-13) cluster have unique expression domains along the anteroposterior and proximodistal axes, respectively, and the establishment of their expression pattern precedes cartilage pattern formation (Yokouchi et al. 1991b). Members of the HoxD complex are expressed in a nested and biphasic manner during limb development (Yokouchi et al. 1991b; Davis and Capecchi 1994). First, the expression is restricted posteriorly (Dollé et al. 1989; Izpisúa-Belmonte et al. 1991; Nohno et al. 1991; Yokouchi et al. $1991 \mathrm{~b}$ ), then the expression domain expands anteriorly as the autopods develop. The second phase of HoxD gene expression suggests a tight correlation of $\operatorname{Hox} D$ genes with the posterior-to-anterior progression of the digital pattern of formation in the autopod. The results of comparative analysis of the expression pattern of HoxD gene in teleost fin buds strongly supports this possibility (Sordino et al. 1995). On the other hand, because the expression pattern is correlated with the segmental bifurcation process of precartilagenous condensation, HoxA genes have been proposed to control the position-specific morphogenesis of the cartilage along the proximodistal axis (Yokouchi et al. 1991b). Positional signaling is required for the establishment of coordinated expression of these Hox genes (Izpisúa-Belmonte et al. 1991; Nohno et al. 1991; Riddle et al. 1993). These findings suggest that Hox genes are candidate genes for controlling the patterning and region-specific morphogenesis of limb cartilage as a prepattern (for review, see Tabin 1992). Recent studies show that animals homozygous to loss-of-function Hox mutations exhibit a defect of cartilage in the normal expression domain (Dollé et al. 1993, Small and Potter 1993; Davis and Capecchi 1994; Favier et al. 1995; Davis et al. 1995). This suggests that these functions of the Hox gene are crucial to control local growth and differentiation of cartilage during limb pattern formation.

In the present study, we investigated the role of Hoxa-
13, which is expressed in the prospective autopod region located in the most distal part of the limb buds during normal development. In later stages of development, the proximal expression boundary of Hoxa-13 lies between the junction of the zeugopod and the autopod. Initiation of Hoxa-13 expression was approximately at stage 22 (Hamburger and Hamilton 1951), where the first phase of the coordinated expression of $\operatorname{Hox} D$ genes has already been established (Yokouchi et al. 1991b). We analyzed the function of Hoxa-13 in the cartilage pattern formation by targeted ectopic misexpression in developing chick embryos using a replication-competent retroviral vector. Hoxa-13 was found to be involved in determining the specificity of homophilic cell-to-cell adhesiveness of limb mesenchymal cells and in controlling growth and differentiation of the cartilage to produce the short bone charactor (carpal bone) in the ankle/wrist.

\section{Results}

Targeted misexpression of Hoxa-13 with a retroviral vector

Previously, we have shown that Hoxa-13 expression is restricted to the presumptive autopod region of the developing chick limb bud (Yokouchi et al. 1991b). To analyze the function of Hoxa-13, we used the ectopic misexpression method with a retroviral vector. First, we developed and established a method for high-frequency infection that would give rise to a nearly entire leg or wing buds in ovo using a recombinant retrovirus carrying an alkaline phosphatase gene (results not shown). Then, we constructed a replication-competent recombinant retrovirus carrying Hoxa-13 cDNA and IRES (internal ribosome entry site from the encephalomyocarditis virus)-Hoxa-13 (Fig. 1 A). IRES-Hoxa-13 was constructed by joining the IRES fragment to the initiation codon of Hoxa-13 cDNA, to increase the amount of the protein product relative to that from the first construct.

To verify the expression of Hoxa-13 mRNA and protein from the recombinant virus, the concentrated virus suspension was injected into the prospective right leg field of stage 10 (Hamburger and Hamilton 1951) chick embryos (Fig. 1B). Two days after injection, the expression pattern was monitored by in situ hybridization using a viral long terminal repeat (LTR) probe (Fig. 1C,D) and a Hoxa-13 probe (Fig. 1E,F) on alternate adjacent sections. As shown in Figure 1C, the LTR probe detected specific signals in the mesenchymal cells of the nearly entire limb bud indicating effective infection by this method. Hoxa-13 signal was also detected in a similar pattern (Fig. 1E). The amount of ectopic Hoxa-13 RNA (Fig. 1E) was comparable to that of the endogenous Hoxa13 mRNA (Fig. 1F) found in the prospective autopod region of the limb buds. Both endogenous and recombinant viral HOXA-13 proteins were detected by whole-mount immunohistochemistry with anti-HOXA-13 polyclonal antibody. In the embryos infected with Hoxa-13 virus, the ectopic expression of HOXA-13 protein was detected in the whole leg bud, although the signal was weaker than that of the endogenous HOXA-13 (Fig. 1G,I). On the 


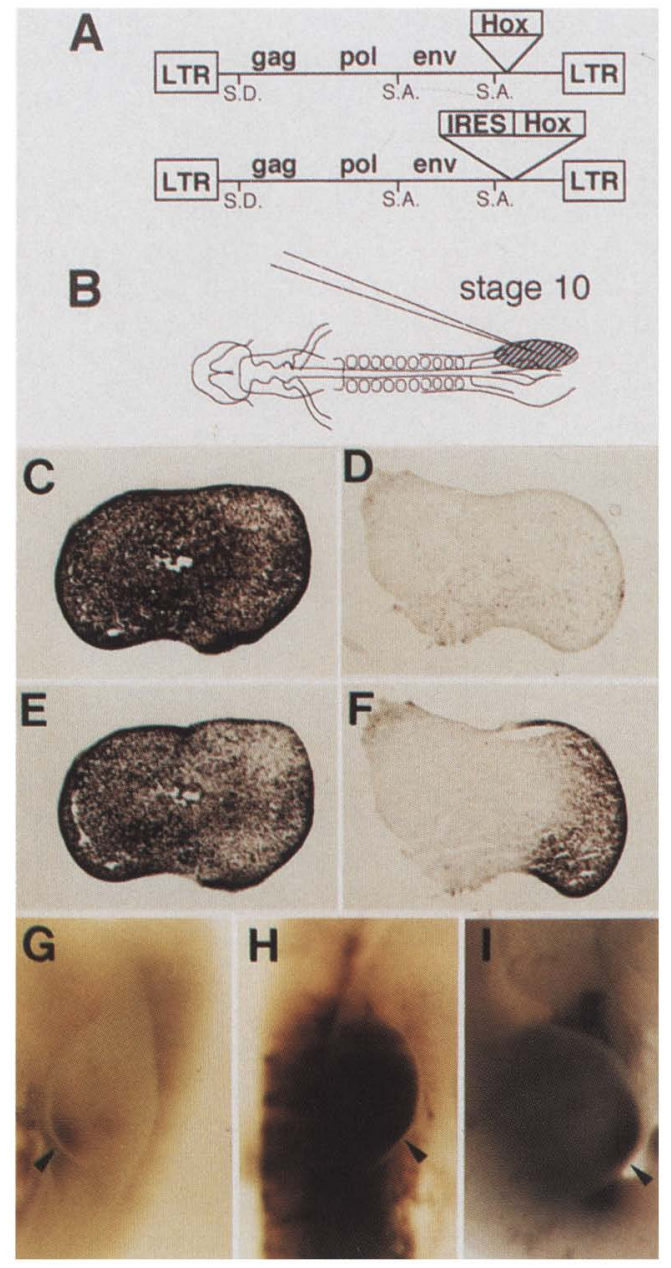

other hand, the amount of protein product from IRESHoxa-13 virus was the same as or more than that produced by the endogenous Hoxa-13 gene (Fig. $1 \mathrm{H}, \mathrm{I}$ ). Thus, Hoxa-13 was misexpressed effectively by this system, changing the amount of protein product.

\section{Reduction in size of zeugopodal cartilages by ectopic Hoxa-13 expression}

Embryos infected with the recombinant viruses were allowed to develop to day 7.5 or 9 and the morphology of the skeletal elements in the injected right limb were analyzed using the left limb as control. In the limbs infected with the Hoxa-13 virus, the zeugopodal cartilages were noticeably reduced in size, whereas the size of the stylopodal cartilage showed only slight reductions (Fig. 2A-D). In contrast the autopodal cartilages showed no alterations in either shape or size. As a control for Hox gene overexpression, Hoxa-4 virus was injected into the prospective limb field in the same way as the Hoxa-13 virus. Chicken Hoxa-4 was expressed in the mesenchymal cells of the entire limb bud (Burke et al. 1995; A. Kuroiwa, unpubl.). In these cases, no changes in the skeletal pattern were observed in the 10 injected limb buds
Figure 1. Replication competent Hox viruses and expression in the limb bud. (A) Structure of Hox viruses. Chicken Hox cDNA or IRES-Hox cDNA was inserted in the replication-competent avian retroviral vector derived from Rous sarcoma virus (see Materials and methods). Three species of mRNA were produced by alternative splicing. Only one species of mRNA from the cDNAs was translatable for Hox protein; however with the IRES sequence, all three mRNAs were assumed be Hox-translatable transcripts. Differences in the amount of the HOXA-13 protein between these constructs are shown below $(H, I) .(B)$ Hox viruses were injected to the prospective right leg field of stage 10 embryos (see Materials and methods). The distribution of the RNA carrying the LTR sequence in Hoxa-13 virus-injected $(C)$ or control $(D)$ limb buds was determined by in situ hybridization 2 days after injection. The whole right leg bud was infected with the recombinant virus $(C)$. The distribution of the RNA carrying the Hoxa-13 sequence was also determined in the injected $(E)$ and control $\langle F\rangle$ limb buds. Expression of the endogenous Hoxa-13 was restricted in the prospective autopod region of the control limb bud at this stage $(F)$. On the other hand, Hoxa-13 transcripts were distributed throughout the whole limb bud infected with Hoxa-13 virus $(E)$. Signal intensity in the injected side $(E)$ was almost equivalent to the endogenous signal $(F)$. The same result was obtained from the embryos infected with IRES-Hoxa-13 virus (results not shown). Distribution of HOXA-13 proteins at stage $22+$ in the control side $(G)$, in the infected side of the Hoxa-13 virus-infected embryos $(I)$, or in the infected side of the IRES-Hoxa-13 virusinfected embryo $(H)$. The arrowhead shows the expression domain of the endogenous HOXA-13 protein. (LTR) Long terminal repeat; (S.D.) splice donor site; (S.A.) splice acceptor site.

(Table 1; data not shown). This suggests that the truncation of the cartilages in the zeugopod observed in the limb infected with Hoxa-13 virus was specific for Hoxa13 function.

Change in the cartilage morphology of the limbs infected with IRES-Hoxa-13 virus was classified as weak (Fig. 2F,I) or strong (Fig. 2G,J) phenotype. In the weak phenotype, the cartilage morphology was nearly the same as that observed in the Hoxa-13 virus-infected limbs. As shown in Table 2, the zeugopodal cartilages were shortened to $\sim 50 \%$ of normal size, and the stylopodal cartilage showed $\sim 20 \%$ reduction in size in the weak phenotype (Fig. 2F,I). No visible changes were observed in the autopodal cartilages. In the strong phenotype, truncation of the skeletal elements was much more severe (Fig. 2G,J); the zeugopodal cartilages were shortened to $30 \%$ of normal size (Table 2). The stylopodal cartilage was shortened to $70 \%$ and the autopodal cartilages were $80 \%$ of normal size (Table 2).

Interestingly, remarkable and specific changes in the cartilage pattern were observed in the zeugopod infected with IRES-Hoxa-13 virus. In normal development, the two zeugopodal cartilage tissues have a diaphysis and an epiphysisis, which are characteristic in the long bone 


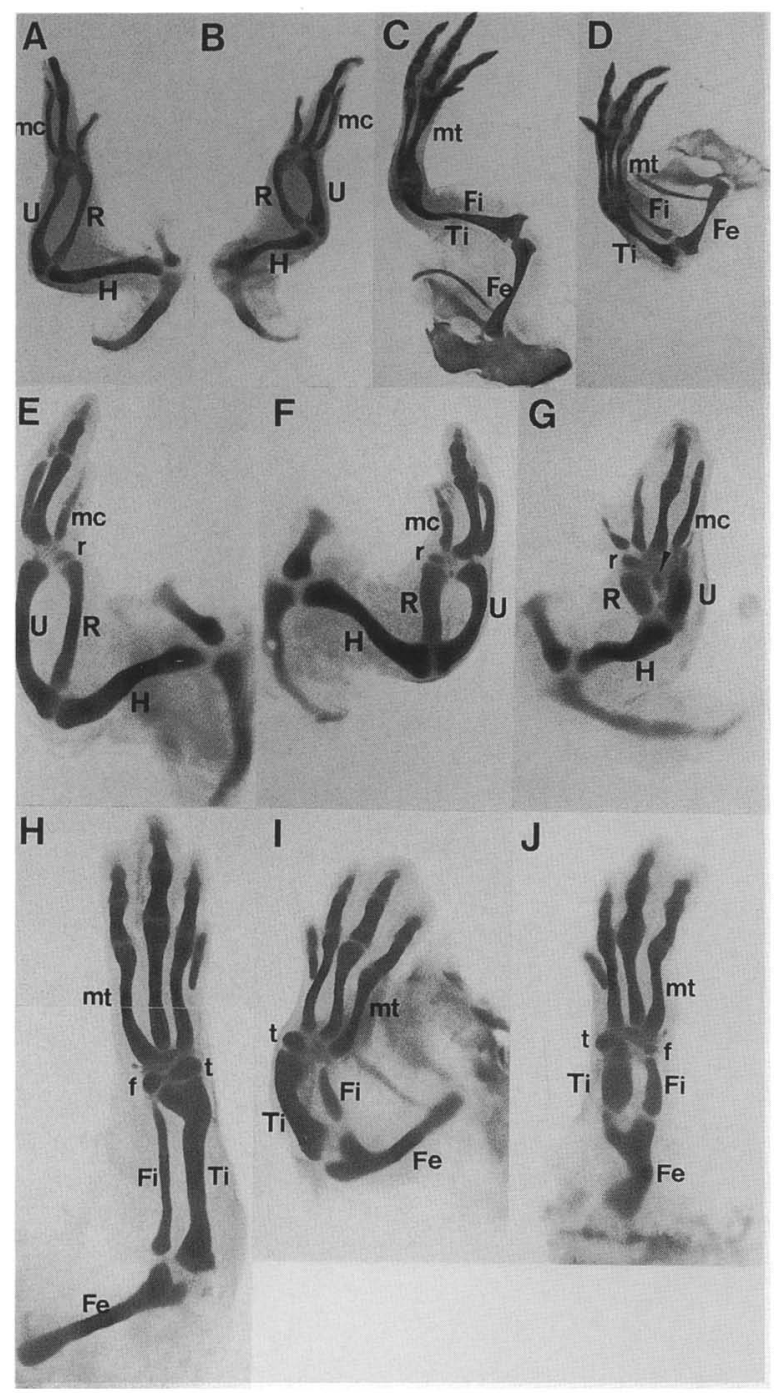

Figure 2. Truncation of cartilages in the zeugopod by Hoxa-13 virus infection. Dorsal view of wing cartilages at day 8 : $(A)$ The left wing as control; $(B)$ the right wing infected with Hoxa-13 virus. Dorsal view of leg cartilages at day $8:(C)$ The left leg as control; $(D)$ the right leg infected with Hoxa-13 virus. In both wing and leg infected with recombinant virus, the zeugopodal cartilages were reduced. Dorsal views of the control left wing $(E)$, of the weak phenotype in the IRES-Hoxa-13 virus-infected right wing $(F)$, and of the strong phenotype $(G)$ at 7.5 days of development are shown. Dorsal views of the left leg as a control $(H)$, of the weak phenotype of the right leg infected with IRESHoxa-13 virus $(I)$, and of the strong phenotype $(I)$ at 7.5 days of development are shown. $(\mathrm{H})$ Humerus; $(\mathrm{R})$ radius; $(\mathrm{U})$ ulna; $(\mathrm{r})$ radiale; (mc) metacarpus; (Fe) femur; (Fi) fibula; (Ti) tibia; (f) fibulare; (mt) metatarsus.

(Fig. 3A,B). On infection with IRES-Hoxa-13 virus, however, they lost the characteristic morphology specific to long bones and were transformed into rounded cartilage (Fig. 3C-E, 3G-J). Moreover, extra cartilages were formed between these two cartilages and the distal region of the zeugopod at high frequency (Table 1; Fig. $3 \mathrm{C}-\mathrm{E}, \mathrm{G}-\mathrm{J})$. These morphological changes in the long bone cartilages were never observed in other positions of the limb bud. In addition, sometimes an extra digit was formed in the region anterior to the anterior-most digit in both wing and leg (Table 1 ; Fig. 3F-H,J). Thus, the ectopic expression of Hoxa-13 resulted in remarkable truncation of the cartilages in the zeugopod. Strong ectopic expression of Hoxa-13 induced morphological changes in the cartilages and caused extra cartilage formation in the zeugopod.

\section{Ectopic Hoxa-13 affected histological pattern of the zeugopodal cartilages}

The transformation of long bone cartilage to round cartilage suggested that ectopic Hoxa-13 expression affected the cell differentiation step of the zeugopodal cartilages. In the tibia on the control side, showing the typical long bone morphology, there were three distinct zones along the proximodistal axis (Fig. 4A) (Fell 1925; Oohira et al. 1974; Stocum et al. 1979). Between the epiphysis and the diaphysis, there is a quiescent zone containing immature polygonal chondrocytes (Fig. 4D), a proliferative zone of disk-shaped proliferating chondrocytes (Fig. 4E), and a hypertrophied zone composed of hypertrophied chondrocytes (Fig. 4F). In addition, the perichondrium surrounds the long bones (Fig. 4C). In the normal development of the tibia, cell division is observed frequently in the proliferative zone and the direction of cell division is perpendicular to the long axis (Fig. 4E). Less frequent cell division takes place in the quiescent zone (Fig. 4D), with similar direction of cell division in the proliferative zone, and rare cell division is observed in the hypertrophied zone (Fig. 4F). In the tibia of the infected side, the typical three-zone structure and the perichondrial layer were lost (Fig. 4B). Instead, precartilagenous mesenchymal cells were observed in the peripheral region at high density (Fig. $4 \mathrm{H}$ ) and immature polygonal chondrocytes were found in the central region (Fig. 4I). These histological features were observed in the quiescent zone of the tibia and in the short bones, such as tibiale in the ankle in normal development (Fig. 4A). In addition, the tissue profile of the extra cartilage formed in the distal region of the tibia was very similar to the tibiale (data not shown). Thus, the tissue of the tibia in the strong phenotype seemed to be transformed to that of the tibiale in the ankle or to that of the quiescent zone in the normal tibia.

To test these two cases, we examined the direction of cell division, which is the only feature to distinguish these two tissues. In the quiescent zone of the normal tibia, the direction of cell division was almost perpendicular to the long axis (Fig. 4D). On the other hand, the direction in the tibiale was not fixed to any angle (Fig. $4 G)$. The directions in virus-infected tibia were completely random (Fig. $4 \mathrm{H}, \mathrm{I}$ ). This result indicates that the long bone cartilage in the zeugopod lost its three-zone structure characteristic to long bone and was transformed to short bone cartilage resembling the tarsus in the ankle as a result of the misexpression of Hoxa-13.

In contrast, no differences were found between experimental and control cartilaginous tissues except in the zeugopod. The metatarsus, the long bone in the autopod, 
Table 1. Effects of Hox virus injection on the limb cartilage pattern

\begin{tabular}{|c|c|c|c|c|c|c|c|}
\hline \multirow[b]{2}{*}{ Limb } & \multirow{2}{*}{$\begin{array}{l}\text { Number of } \\
\text { virus injected } \\
\text { limb buds }\end{array}$} & \multicolumn{2}{|c|}{ Cartilage pattern } & \multicolumn{2}{|c|}{ Phenotype } & \multirow{2}{*}{$\begin{array}{l}\text { Ectopic } \\
\text { cartilage in } \\
\text { the zeugopod }\end{array}$} & \multirow[b]{2}{*}{ Extra digit 1} \\
\hline & & normal & affected & weak & strong & & \\
\hline \multicolumn{8}{|l|}{ Wing } \\
\hline Hoxa-4 & 10 & 10 & 0 & - & 一 & - & - \\
\hline Hoxa-13 & 10 & 3 & 7 & 7 & 0 & - & - \\
\hline IRES-Hoxa-13 & 52 & 9 & 43 & 17 & 26 & 15 & $8^{a}(3)^{b}$ \\
\hline \multicolumn{8}{|l|}{ Leg } \\
\hline Ноха-4 & 10 & 10 & 0 & - & - & - & - \\
\hline Hoxa-13 & 12 & 5 & 7 & 7 & 0 & - & - \\
\hline IRES-Hoxa-13 & 69 & 10 & 59 & 35 & 24 & 17 & 2 \\
\hline
\end{tabular}

Limbs were dissected 6 or 8 days after virus injection and cartilages were stained as described in Materials and methods. Limbs carrying any alteration in cartilage pattern were scored. Cartilages from IRES-Hoxa-13-infected limb showing a similar extent for truncation as found in Hoxa-13 virus were classified as "weak" phenotype, and more severe phenotype was classified as a "strong" phenotype. Production of HOXA-4 protein from the recombinant viruses was confirmed by Western blot analysis using cell lysate of the chicken embryonic fibroblast cells infected with recombinant viruses and specific antibodies (Prep.)

${ }^{a}$ Extra digit 2 appeared in the position anterior to the normal digit 2.

${ }^{b}$ Two extra digits appeared in the position anterior to the normal digit 2 .

and the femur, the long bone in the stylopod, still maintain the three-zone structure in the virus-infected limbs. No changes were found in the tibiale, fibulare, and distal tarsus 2 and 3.

\section{Ectopic Hoxa-13 expression affects differentiation of cartilage cells}

The morphological and histological changes in the zeugopodal cartilages induced by ectopic Hoxa-13 expression were assumed to be attributable to alteration of the process of cartilage differentiation. We analyzed the effect of misexpression of Hoxa-13 on cartilage cell differentiation by monitoring the expression profile of differentiation-specific marker genes at day 7. During normal development, these marker genes are expressed in a differentiation stage-specific manner in the long bone cartilage. Proteoglycan-H (PG-H), a cartilage-specific proteoglycan core protein, is expressed in the mesenchymal cells from the stage of precartilagenous condensation to mature cartilage (for review, see Stirpe and Goetinck
1989). Proteoglycan-Lb (PG-Lb) is expressed in a subpopulation of immature chondrocytes in the quiescent zone and disk-shaped chondrocytes in the proliferative zone but is not expressed in hypertrophied chondrocytes (Shinomura et al. 1984). Type X collagen (ColX) expression is restricted to the hypertrophied chondrocytes in the hypertrophied zone (Linsenmayer et al. 1991).

The expression pattern of PG-H was not affected by Hoxa-13 misexpression (Fig. 5A,D), whereas those of the other markers showed obvious changes. In the zeugopodal cartilages of the uninjected control side, PG-Lb was expressed in the epiphysis and disappeared from the center of the diaphysis (Fig. 5B). In the injected side, PG-Lb was detected in whole cartilage of the zeugopod, including the central region where expression was not seen in normal development (Fig. 5E). In the control side, ColX was expressed in the center of the diaphysis of the zeugopodal cartilages (Fig. 5C), whereas no ColX expression was detected in the injected side (Fig. 5E). On the other hand, in the long bones in the stylopod and in the autopod, the expression patterns of all three marker genes in

Table 2. Measurement of cartilage shortening induced by IRES-Hoxa-13 virus

\begin{tabular}{lcccc}
\hline Limb $^{\mathrm{a}}$ & Humerus/femur $^{\mathrm{b}}$ & Radius, ulna/tibia, fibula $^{\mathrm{b}}$ & Carpus/tarsus $^{\mathrm{b}}$ & Metacarpus/metatarsus $^{\mathrm{b}}$ \\
\hline Wing & & & & $0.95 \pm 0.07$ \\
$\quad$ weak $(n=17)$ & $0.87 \pm 0.04$ & $0.52 \pm 0.08$ & $0.97 \pm 0.05$ & $0.89 \pm 0.05$ \\
$\quad$ strong $(n=26)$ & $0.70 \pm 0.04$ & $0.34 \pm 0.03$ & & $0.86 \pm 0.05$ \\
Leg & & & $0.82 \pm 0.03$ & $0.86 \pm 0.04$ \\
$\quad$ weak $(n=35)$ & $0.82 \pm 0.03$ & $0.69 \pm 0.06$ & $0.98 \pm 0.02$ & $0.79 \pm 0.05$ \\
$\quad$ strong $(n=24)$ & $0.69 \pm 0.04$ & $0.29 \pm 0.04$ & \\
\hline
\end{tabular}

Each limb was set flat, and the cartilage pattern was photographed under the low magnification microscope at the same magnification. After printing at the same ratio of enlargement, the length of each cartilage was measured with a ruler. Then the ratio was calculated using the length of control side as a standard. Values are the mean \pm S.E.M. The mean was estimated by setting up the $95 \%$ confidential interval about the mean. Weak and strong phenotypes were described in Table 1.

${ }^{a}$ Number $(n)$ of limbs showing transformation by injection of IRES-Hoxa-13 virus.

${ }^{\mathrm{b}}$ The ratio of the cartilage length of IRES-Hoxa-13-injected limb to that of control limb. 

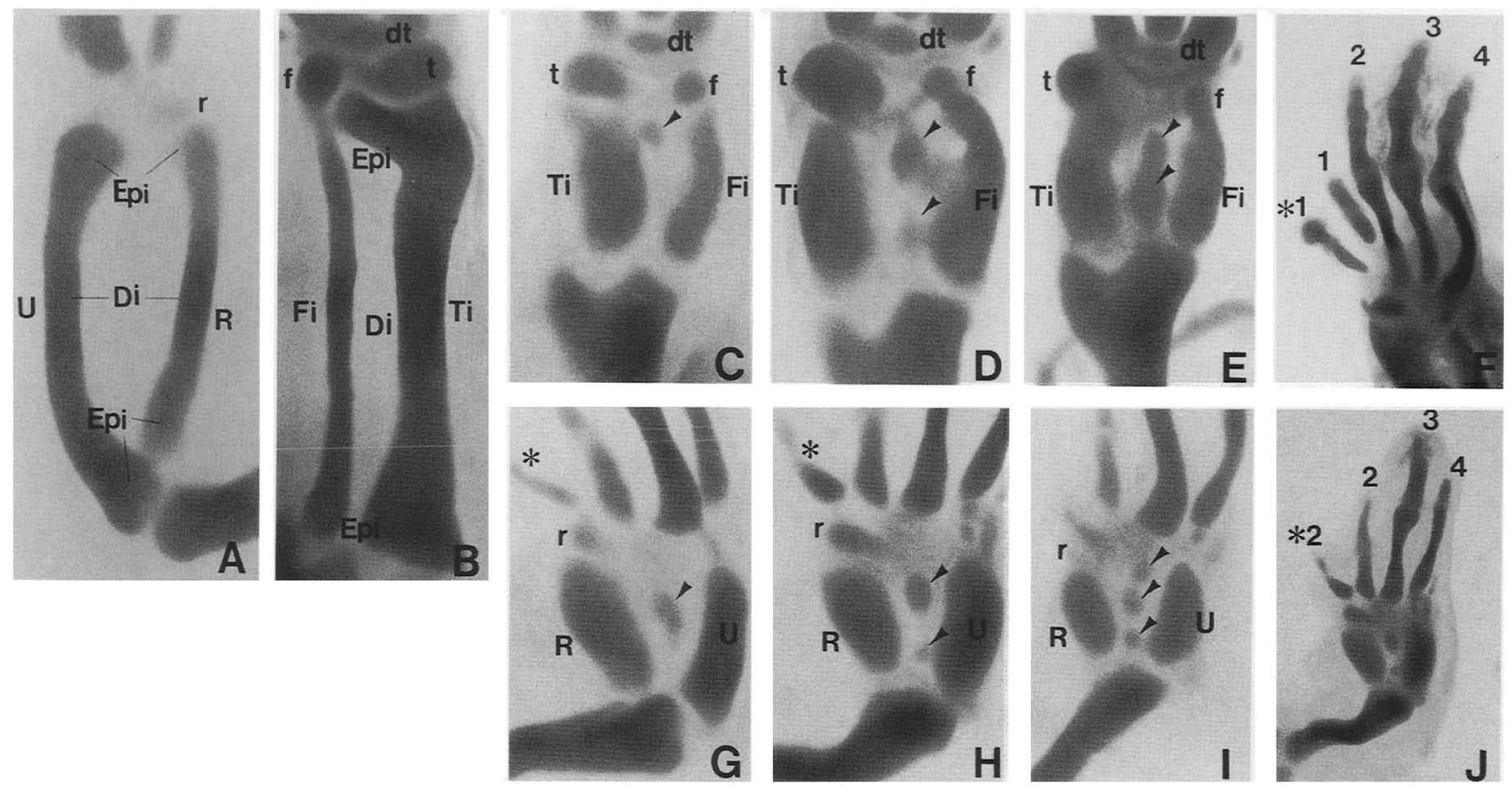

Figure 3. Morphological changes and ectopic cartilage formation in the zeugopod. High magnification view of the zeugopod in a control left wing $(A)$ and leg $(B)$. The epiphysis (Epi) and diaphysis (Di) of the radius, ulna, and tibia are indicated. High magnification view of the zeugopod in the strong phenotype limb induced by IRES-Hoxa-13 virus injection into the right leg $(C-F)$ or right wing $(G, H)$. The zeugopod cartilages have lost the characteristic morphology as the long bone. Ectopic cartilage was observed between the tibia and the fibula or the radius and the ulna (arrowheads). Occasionally, an extra digit, indicated by an asterisk (*), was formed anterior to the original digit $l|F|$ in leg and digit 2 in wing $(G, H, J)$. $(\mathrm{R})$ Radius; $(\mathrm{U})$ ulna; $(\mathrm{r})$ radiale; (Ti) tibia; $(\mathrm{Fi})$ fibula; $(\mathrm{t})$ tibiale; $(\mathrm{f})$ fibulare; (dt) distal tarsus.

the injected side were not affected (Fig. 5D-F). These results suggest that the ectopic expression of Hoxa-13 specifically repressed terminal differentiation of the chondrocytes in the long bones of the zeugopod.

\section{Stage of cartilage differentiation affected by ectopic Hoxa-13 expression}

Both the mass of the initial precartilagenous condensation and the growth rate of cartilage after condensation determine the length of cartilage (Hinchliffe and Johnson 1980). In the leg bud, condensation in the zeugopod is complete at stage 25 , just after which the cartilaginous rudiments in the zeugopod begin to grow and continue to grow until hatching (Summerbell 1976). To determine the crucial step for cartilage size reduction by ectopic Hoxa-13 expression, we examined the condensation pattern using PG-H as an indicator in the leg bud at stages 24 and 26. At stage 24, in the control side, the cartilaginous rudiments in the zeugopod were complete for condensation and cartilaginous rudiments in the autopod began to form (Fig. 6C). In the injected side, the length of the fibula rudiment was slightly shorter than that of the control side (Figure 6D). On the other hand, the lengths of the tibia rudiment on the injected side was equivalent to that on the control side (Fig. 6E,F). Interestingly, many small cartilaginous condensations were observed ectopically between the fibula and the tibia, near the fibula, and in the distal portion of the tibia rudiment (Fig. $6 \mathrm{G}, \mathrm{H})$. These results suggest that the precartilagenous condensation process in the zeugopod was also affected by the ectopic expression of Hoxa-13.

Size reduction of the primary precartilagenous condensation was insufficient to explain the final phenotype. Thus, we postulated that the main cause may be the arrest of growth; therefore, we examined the cartilage pattern 1 day after the above observations. At this stage (stage 26), although the length of the tibia and the fibula on the control side were twice those at stage 24 , in the injected side both were almost equivalent in length to those at stage 24 (Fig. 6I-L). The width of the tibia in the control side was 1.5 times that in the injected side. These results indicated that growth arrest of the zeugopodal cartilages already took place between stages 24 and 26. Considering the extent of size reduction in the final stage of our observation (6.5-8 days of incubation), growth arrest seemed to continue at least to this stage. In addition, the accumulation of PG-H mRNA was not affected by ectopic Hoxa-13 expression, suggesting that ectopic Hoxa-13 arrested cell proliferation in cartilage rudiments just after condensation.

\section{Involvement of Hoxa-13 in cell-to-cell adhesion}

The ectopic expression of Hoxa-13 resulted in formation of ectopic precartilagenous condensation. This suggested the involvement of Hox genes in the condensation process through control of cell-to-cell adhesiveness. The mesodermal cells derived from different positions at a given stage of limb bud development and cells in the 

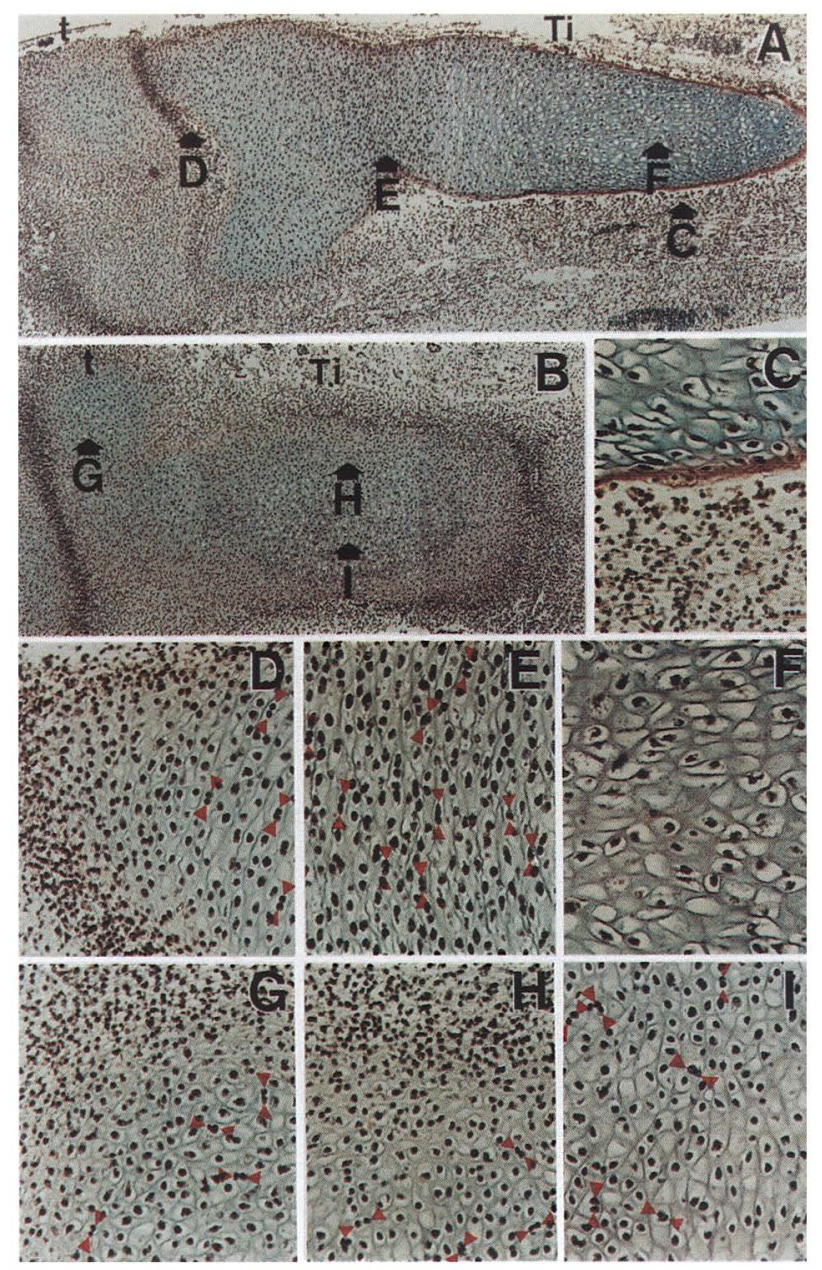

Figure 4. Tissue profile of the tibia in the strong phenotype. Limbs representing the strong phenotype at day 7.5 were dissected out and embedded in paraffin, sectioned, and stained with hematoxilin and eosin. Histological views show control $(A, C-F)$ and IRES-Hoxa-13-injected $(B, G-I)$ leg cartilages in the zeugopod. Thick arrows labeled $\mathrm{C}$ and $\mathrm{D}$ in $A$ and labeled $\mathrm{G}-\mathrm{I}$ in $B$ indicate the positions for the analysis at higher magnification shown below. Typical pattern of the perichondrium surrounding the long bone was observed in control $(C)$; however, no such pattern was observed in the injected limb bud $(B)$. High magnification views of the tissue from the quiescent zone $|D|$, the proliferative zone $(E)$, and hypertrophic zone $(F)$ of normal tibia are shown. High magnification views of the tibiale $\{G\}$, peripheral region $(H)$, and central region $(I)$ of the tibia infected with IRES-Hoxa-13 shows the strong phenotype. The direction of cell division in $D, E, G-I$ is indicated with red triangles. (Ti) Tibia; $(\mathrm{t})$ tibiale.

progress zone at different developmental stages show different cell-to-cell adhesion properties in vitro (Ide et al. 1994). Therefore, we examined the correlation between Hoxa-13 expression and cell-to-cell adhesiveness.

The mesenchymal cells expressing HOXA- 13 from the distal region of quail limb bud, which is equivalent to chick stage 24, and non-HOXA-13-expressing mesenchymal cells from chick marginal zone at stage 24 were dis- sociated, mixed, and cultured at high cell density (Fig. 7A). The quail distal cells and the chick proximal mesodermal cells were completely sorted from each other after $24 \mathrm{hr}$ of incubation (Fig. 7B-D). Continuous expres-

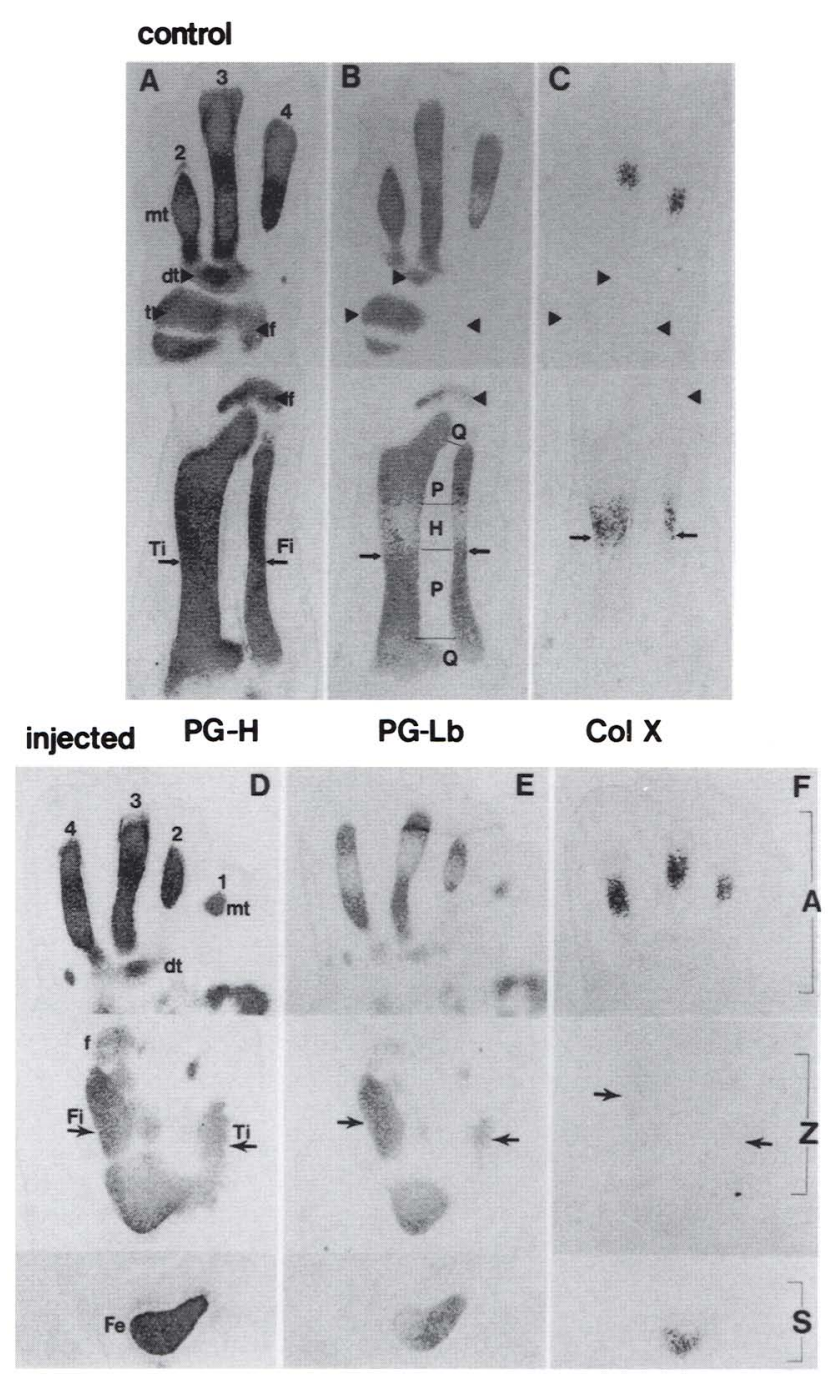

Figure 5. Expression of cartilage differentiation marker genes. Limbs showing the strong phenotype at day 7 were sectioned serially and analyzed for the expression patterns of cartilage differentiation marker genes by in situ hybridization. $(A-C)$ The sections from the control left leg were hybridized with PG-H probe $\{A \mid$, PG-Lb probe $(B)$, or ColX probe $(C)$. Arrowheads in $B$ and $C$ indicate the positions of each cartilage seen in $A$. A and $\mathrm{Z}($ right $)$ indicate the autopod and zeugopod, respectively. $(D-F)$ The sections of the virus-infected right leg were hybridized with PG-H probe $(D)$, PG-Lb probe $(E)$, or with type $\mathrm{X}$ collagen probe $(F)$. Arrows in $E$ and $F$ indicate the positions of the fibula and tibia similarly to those in D. A, Z, and S (right) indicate the autopod, zeugopod, and stylopod, respectively. During normal development of the long bone cartilage, $\mathrm{PG}-\mathrm{H}$ is expressed in all chondrocytes. PG-Lb is expressed in the chondrocytes of quiescent and proliferative zone, and ColX collagen is expressed specifically in hypertrophic chondrocytes. Arrows indicate the ectopic cartilage. (Fe) Femur; (Ti) tibia; (Fi) fibula; $(\mathrm{t})$ tibiale; (f) fibulare; (dt) distal tarsus; $(\mathrm{mt})$ metatarsus; (1-4) digit numbers; $(\mathrm{H})$ hypertrophic zone; $(\mathrm{P})$ proliferative zone; $(\mathrm{Q})$ quiescent zone. 

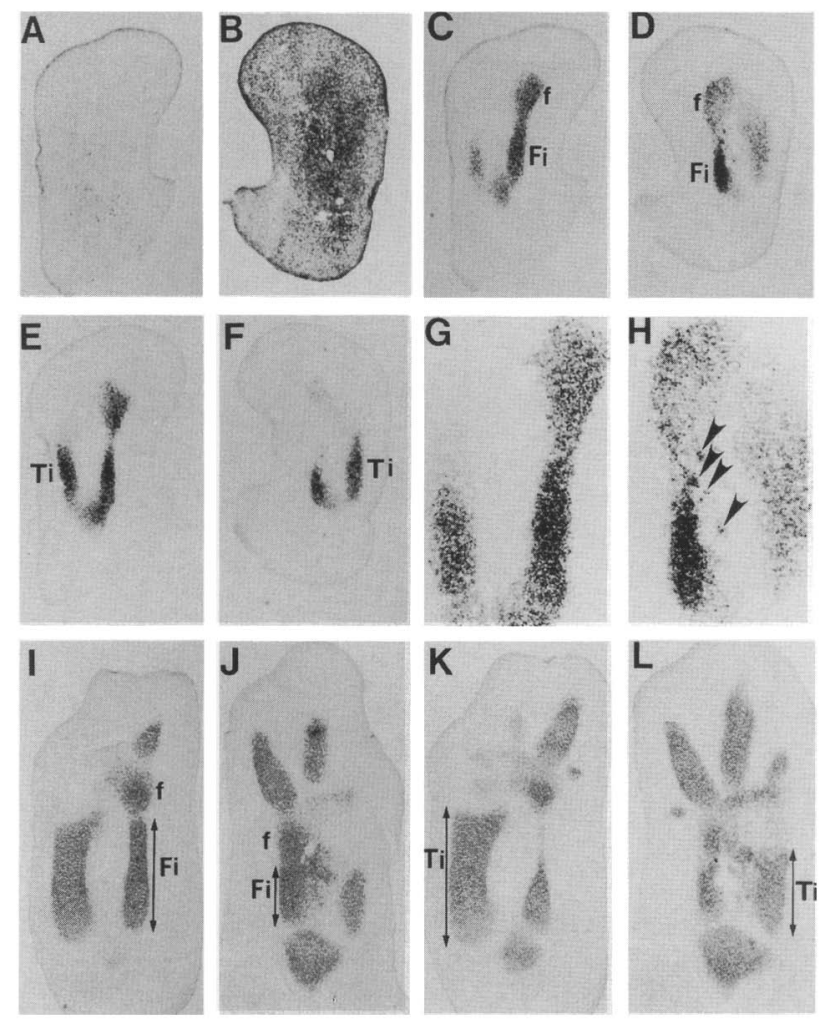

Figure 6. Precartilagenous condensation pattern of Hoxa-13 misexpression in limb buds at early stages. IRES-Hoxa-13 virus was injected into the prospective leg field at stage 10 , tissue was harvested at day 4 (stage $24 ; A-H$ ) or day 5 (stage $26 ; I-L)$, fixed, and cut into serial sections, and the precartilagenous condensation pattern was analyzed by determining the expression of the cartilage-specific proteoglycan core protein PG-H. The distributions of viral LTR transcripts either in the control left leg $(A)$ or in the infected right leg $(B)$ allowed visualization of the area of recombinant virus infection. Infection was seen in the mesenchymal cells of nearly the entire limb buds. $(C-H)$ Sections hybridized with PG-H probe. $(C, D)$ Comparison of the length of the fibula rudiment either in the control left leg $(C)$ and in the infected right leg $(D) .(E, F)$ Comparison of the length of the tibia rudiment in the control left leg $(E)$ and the infected right leg $(F)$. $(G, H)$ Higher magnifications of $C$ and $D$. Arrowheads show small ectopic condensations. $(I-L)$ The leg buds were harvested at stage 26, sectioned, and hybridized with PG-H probe. $(I, J)$ Comparison of the length of the fibula in the control left leg $(I)$ and in the virus-infected right leg $(/)$. Arrowheads show both ends of the fibula. $(K, L)$ Comparison of the length of the tibia in the control left leg $(K)$ and in the virus-injected right leg $(L)$. Arrowheads show the both ends of the tibia. (Ti) Tibia; (Fi) fibula; (f) fibulare.

sion of HOXA-13 was observed in the quail distal mesoderm during incubation (Fig. 7B,C), whereas chicken HOXA-13 was not expressed at any point during the incubation. Total cell number was increased from 0 to a maximum of $50 \%$ during the incubation period; however, no change in the ratio of HOXA-13-expressing to HOXA-13-nonexpressing cells was observed. Therefore, we can exclude the possibility that aggregate formation of HOXA-13-expressing cells was attributable to de novo expression of HOXA-13 or clonal expansion from HOXA-13-expressing cells during incubation. In addition the limb mesenchymal cells from chick and quail never sorted out in the mix culture if their developmental stage and position in the limb bud were equivalent (Ide et al. 1994; data not shown). Hence, we concluded that HOXA-13-expressing cells reassociated in a homophilic manner and formed aggregates.

In the above experiment, the cells in the distal region, and the cells in the more proximal region of the limb buds were in different phases of the differentiation process. It is possible that this difference was responsible for the observed cell sorting. Therefore, we isolated the limb mesenchymal cells from the progress zone at different developmental stages. These cells are considered to be in the same differentiation state. The quail progress zone cells expressing HOXA- 13 at stage 25 and the chick progress zone cells from stage 20 , which were not yet expressing HOXA-13, were dissociated and mixed (Fig. 7E). They were sorted from each other after $24 \mathrm{hr}$ of incubation (Fig. 7F-H). This result excludes the possibility that the observed sorting was attributable to the difference in differentiation stage of limb mesenchymal cells.

Finally, to demonstrate conclusively the direct involvement of Hoxa-13 in controlling the homophilic cell-to-cell adhesiveness, we examined the behavior of the limb mesenchymal cells misexpressing Hoxa-13. The IRES-Hoxa-13 virus was injected into the prospective leg field at stage 10 followed by incubation until stage 20 at which stage endogenous Hoxa-13 was not yet expressed. Then, limb mesenchymal cells were isolated and cultured for $24 \mathrm{hr}$ (Fig. 7I). Approximately $30 \%$ of the cells expressed virus-encoded HOXA-13, and these cells reassociated and were sorted from HOXA-13-nonexpressing cells (Fig. 7J-L). As a control, limb mesenchymal cells infected with alkaline phosphate (ALP) virus were used instead of Hoxa-13-infected cells; reassociation of ALP-positive cells was not significant (Fig. 7MO). The HOXA-13-expressing cells in Figure 7K formed a clear nodule, but ALP-positive cells in Figure $7 \mathrm{~N}$ never formed the nodule. During the incubation period, the ratio of HOXA-13-positive cells was not changed significantly $(32 \%$ at $0 \mathrm{hr}$ and $28 \%$ at $24 \mathrm{hr})$. This evidence and that of ALP-positive cells not showing significant aggregation (Fig. $7 \mathrm{M}-\mathrm{O}$ ) exclude the possibility that aggregation of HOXA-13-positive cells was formed by a secondary infection of the IRES-Hoxa-13 virus to neighboring cells during the incubation period. These results show that Hoxa-13 somehow controls the specificity of homophilic cell-to-cell adhesiveness.

\section{Discussion}

\section{Involvement of Hoxa-13 in growth and differentiation of cartilage}

As Hox genes are expressed in the limb mesenchyme cells during pattern formation of precartilagenous condensation and the perichondrium during cartilage growth/differentiation, it was proposed that Hox genes 


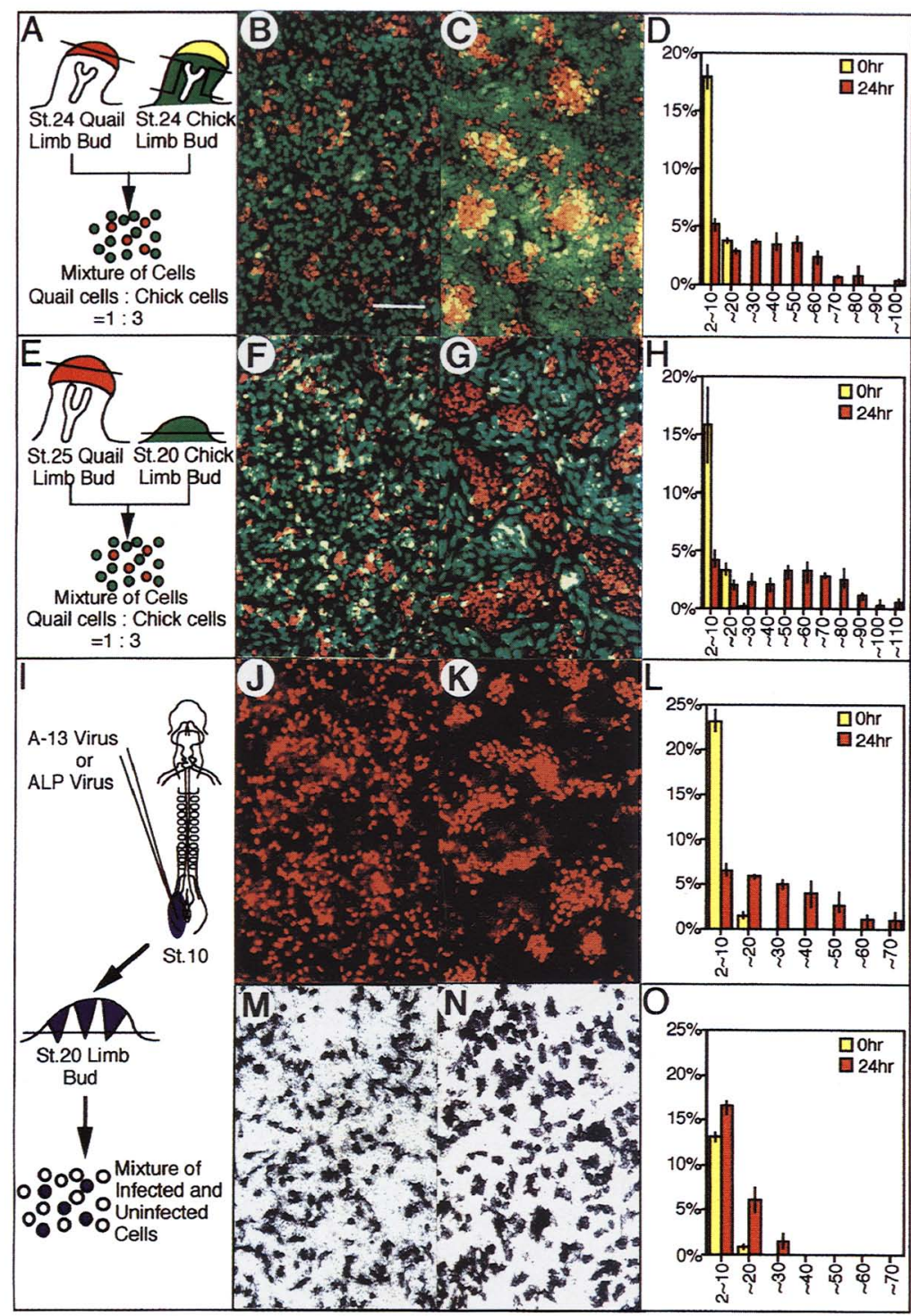

Figure 7. Hoxa-13 alters the cell-to-cell adhesiveness of the limb mesenchymal cells. $(A-D)$ Correlation of Hoxa-13 expression with the differences in cell-to-cell adhesiveness along the proximodistal axis. (A) Experimental procedure. Distal mesodermal cells of the quail limb bud at stage 24 (Hoxa-13-positive) and the proximal marginal mesodermal cells of the chick limb bud at stage 24 (Hoxa-13-negative) were mixed in high-density culture (Ide et al. 1994). Cells in culture were then double stained using the chick-specific monoclonal antibody A223 and anti-HOXA-13 polyclonal antibody at $0 \mathrm{hr}(B)$ or after $24 \mathrm{hr}(C)$ of incubation. Chick cells were identified by their green signal, and HOXA-13-positive cells were visualized as red signals. (B) Bar, $100 \mu \mathrm{m}$. (D) Quantitative analysis of the ratio of HOXA-13-positive cells in the aggregates. The ratio of the HOXA-13-positive cells in each aggregate to total number of HOXA-13 positive cells is shown on the ordinate. The abscissa indicates the number of the HOXA-13-positive cells in the aggregate. $(E-H)$ Cell sorting between HOXA-13-expressing and nonexpressing cells at the equivalent cell differentiation stage (progress zone cells) at different developmental stages. $(E)$ Experimental procedure. Distal mesodermal cells of the quail limb bud at stage 24 (Hoxa-13-positive) and distal mesodermal cells of the chick limb bud at stage 20 (Hoxa-13-negative) were mixed in highdensity culture. Cells in culture were stained using chick-specific monoclonal antibody A223 (green) and anti-HOXA-13 polyclonal antibody (red) at $0 \mathrm{hr}(F)$ or after $24 \mathrm{hr}(G)$ of incubation. $(H)$ Quantitative analysis of the number of HOXA-13positive cells in the aggregates. $(I-O)$ Cell sorting in the Hoxa-13-misexpressing limb mesenchymal cells. (I) Experimental procedure. IRES-Hoxa-13 virus or ALP virus was injected into the prospective leg field at stage 10 . Embryos were harvested at stage 20 , and the mesoderm of the leg bud was dissociated to single cells and incubated in highdensity culture. Cells from limb buds infected with Hoxa-13 virus were stained with anti-HOXA13 polyclonal antibody at $0 \mathrm{hr}(J)$ or after $24 \mathrm{hr}(K)$ of incubation. The population of cells expressing virus-derived HOXA-13 was $32 \%$ in this experiment, and the same result was obtained with $23 \%$ infection but not with $13 \%$ infection. Cells from ALP virus-infected limb buds were analyzed by means of the exogenous ALP activity at $0 \mathrm{hr}(M)$ or after $24 \mathrm{hr}(N)$ of incubation. In this case, the population of ALP-positive cells was $21 \%$. Quantitative analysis of cell sorting of either Hoxa-13 virus-infected cells $(L)$ or ALP virus-infected cells $(O)$.

might control the cell adhesiveness and growth/differentiation of the cartilage (Yokouchi et al. 1991b). Infection with Hoxa-13-containing recombinant viral vectors allowed efficient misexpression of Hoxa-13 and induced truncation of the cartilages in the zeugopod (Figs. 2 and 3). The extent of the shortening was proportional to the amount of the ectopic HOXA-13 protein expressed. In addition, no changes in the cartilage pattern were observed by injection of Hoxa-4 virus. Misexpression of Hoxd-11 in limb bud was shown to induce homeotic transformation of the anterior cartilage to the more posterior cartilage (Morgan et al. 1992). The phenotype of this transformation is different from the phenotype induced by Hoxa-13 misexpression. These results suggest that the phenotype induced by Hoxa-13 misexpression is unique and specific for Hoxa-13 and indicate that Hoxa13 is involved in the negative regulation for growth and differentiation of cartilage.

In the developing limb bud, the factors that most influence the final length of the cartilages are the mass of the initial condensation during the cartilaginous rudiment-forming phase and the expansion during the secondary growth phase. In the strong phenotype at stage 24 (just after completion of the condensation in the zeugopod), a slightly smaller initial condensation was formed in the zeugopod; however, this was not sufficient to explain the final phenotype. At stage 26, 1 day later, the cartilages in the infected side showed insignificant growth, whereas rapid growth was observed in normal development. These observations indicate that the size 
reduction of the cartilage length in this experiment was caused by arrest of the growth during the early cartilage growth phase.

During cartilage differentiation, clear morphological and histological changes were observed in Hoxa-13-misexpressing limbs (Fig. 2-4). In the strong phenotype at the late cartilage growth stage, the zeugopodal cartilages lost the three-zone structure characteristic of the long bone. Moreover, ColX mRNA, a specific marker gene for the hypertrophic zone, was not detected in the strong phenotype. These results suggest that Hoxa-13 is involved in down-regulation of cartilage differentiation at the late stage. The differentiation (maturation) of the long bone cartilage progresses successively, beginning from the quiescent zone, turning into the proliferative zone, and finally completing in the hypertrophic zone. The loss of the proliferative zone in the strong phenotype indicates that the chondrocytes in the quiescent zone did not follow the normal differentiation pathway. Hence, repression of differentiation at this step is the main reason for the arrest in cartilage differentiation of the zeugopod misexpressing Hoxa-13. Two mechanisms may be proposed to explain this effect. The first possibility is that Hoxa-13 regulates the expression of the growth factors controlling cartilage growth and differentiation. Various transforming growth factor- $\beta$ (TGF- $\beta$ )-related genes are expressed at each step of cartilage development and affect cartilage differentiation (for review, see Lyons et al. 1990; Leonard et al. 1991; Millan et al. 1991; Storm et al. 1994), and it has been proposed that the successive progression of cartilage differentiation may be regulated by these factors. In the growth stage cartilage of normal embryo, Hoxa-13 is also expressed in the peripheral region of the epiphysis. Considering the overlapping expression of TGF- $\beta 3$ (Millan et al. 1991), GDF (growth/ differentiation factor)-5 (Storm et al. 1994), and Hoxa-13, the involvement of Hoxa-13 in the regulation of these genes is anticipated. Alternatively, Hoxa-13 may affect the cartilage growth and differentiation indirectly through regulation of other transcription factors. Cells in the tibia expressing Hoxa-13 ectopically showed mitosis in random directions, which is characteristic of the short bone in normal development. During the normal development of the ankle/wrist cartilages, such a random direction of mitosis was retained, although expression of Hoxa-13 ceased in the center of the cartilage. This suggests the presence of an unknown transcription factor controlling the randomized division in the short bone cartilage.

The main argument in opposition to our proposal is that ectopic expression of Hoxa-13 in chondrocytes might alter the growth and differentiation mode in a nonspecific manner. Similarly to other Hox genes expressed in the limb bud (Dollé et al. 1989), Hoxa-13 is expressed in the limb mesenchymal cells and its expression ceases in the chondrocytes but is retained in the cells in the perichondrium (Yokouchi et al. 1991b). However, in the case of our virus constructs, continuous expression of Hoxa-13 gene in the chondrocytes has been observed. In the limb infected with Hoxa-13 virus, Hoxa-
13 was also expressed continuously in the chondrocytes not only of the zeugopod but also of the autopod. Even in the strong phenotype, although long bones in the autopod showed slight truncation, histologically and morphologically normal long bones developed in the autopod. Thus, it is unlikely that misexpression of Hoxa-13 in chondrocytes nonspecifically repressed growth or chondrogenic differentiation. We conclude that the repressive effect of Hoxa-13 on cell growth and differenti ation is unique to the mesenchymal cells in the zeugopod.

\section{Homeotic transformation of limb cartilage}

The mature cartilage is classified morphologically and histologically as the long bone and the short bone. The rudiments formed in the stylopod, zeugopod, and autopod, except for the carpus/tarsus, grow rapidly and differentiate to the long bone with a characteristic threezone structure. On the other hand, the rudiments formed in the carpus/tarsus show little or no growth and differentiate to the short bone consisting of immature chondrocytes.

Strong misexpression of Hoxa-13 induced severe truncation of the long bone cartilages in the zeugopod. The precartilagenous condensation at the early stage was equivalent in size to that of the initial condensation, indicating that this cartilage did not grow. The final morphology of the transformed cartlage was globular and was constructed of immature chondrocytes whose mitotic directions were random. Moreover, the expression patterns of three differentiation markers were the same as those in the short bone. These observations suggest that a homeotic transformation of the long bone to the short bone occurred in the zeugopodal cartilages (i.e., a transformation from proximally to distally). In gain-offunction experiments of Hox genes, it has been shown that homeotic transformation of the vertebrae or rib is restricted to the region anterior to the normal expression domain (for review, see Balling et al. 1989; Lufkin et al. 1992; Morgan et al. 1992). In this study homeotic transformation was detected in the zeugopod alone, where Hoxa-13 was not expressed originally. This positional restriction agreed with the general rule of posterior prevalence (for review, see Duboule and Morata 1994; Krumlauf 1994).

Finally, from these results, one important function of Hoxa-13 in normal development is assumed to be the programming of the cartilage rudiments in the ankle/ wrist to develop as the short bone. Hoxa-13 is expressed in the autopod region where both short bones (carpus/ tarsus) and long bones (metacarpus/metatarsus and phalanx) exist in the proximodistal order. Inconsistency arising from restriction of Hoxa-13 function in determining short bone identity may be explained by the partially overlapping expression domain of Hoxd-13, a paralog gene of Hoxa-13 in the HoxD cluster, in the autopod. At later stages in limb development Hoxd-13 was expressed in more distally restricted regions and the proximal boundary of which lay in the junction between carpus/ tarsus and metacarpus/metatarsus (Yokouchi et al. 1991b). In the Hoxd-13 expression domain, cartilage ru- 
diments differentiated to long bone. This suggests the possibility that Hoxd-13 somehow overcomes repressive function of Hoxa-13 in chondrogenesis and results in differentiation as a long bone in the overlapping region of Hoxa-13 and Hoxd-13 expression domains. Alternatively, HOXA-13 may have a weaker transcriptional activating potential than that of HOXA-11 and HOXD-11. Apparent antagonizing activity of Hoxa-13 in misexpressed zeugopod would result from a kind of competition by a less efficient activator (HOXA-13) to common target genes that regulate growth and differentiation of cartilage. HOXD-13 may also have a weaker transcription-activating potential, and cooperation of HOXA-13 and HOXD-13 would be required for the development of metacarpal/metatarsal and phalanx cartilage as long bone. These possibilities are supported by the phenotype of Hoxd-13-disrupted mouse. In these embryos, the partial reduction of cartilaginous condensation within the Hoxd-13 expression domain was observed (Dollé et al. 1993). The requirement of such a subtle balance in the amounts of Hox proteins for proper pattern formation and the combinatorial rule were also suggested previously in the vertebra and rib morphogenesis (Jegalian and De Robertis 1992; Pollock et al. 1992; Rancourt et al. 1995), which supports our hypothesis.

\section{Hoxa-13 and cell-to-cell adhesiveness}

Branching and segmenting bifurcation of precartilagenous condensation occurred in the initial process of cartilage pattern formation, but the molecular mechanism is still not known. One of the important factors controlling this process was postulated to be changes in homophilic cell-to-cell adhesiveness of limb mesenchymal cells at the point of bifurcation (Oster et al. 1988). Differences in the cell-to-cell adhesiveness dependent on the position or on the stage in the developing limb bud were demonstrated (Ide et al. 1994). From the correlation of the expression domain and the segmentation process, we proposed that Hoxa-13 may control the segmentation bifurcation process of the precartilaginous condensation by regulating the cell-to-cell adhesiveness of the limb mesenchymal cells along the proximodistal axis (Yokouchi et al. 1991b).

In this study we found that extra cartilage was formed between the two cartilage components of the zeugopod in response to the ectopic strong expression of Hoxa-13. An indication of this phenomenon was observed just after completion of the condensation in the zeugopod with the formation of many minute condensations between the tibia and fibula rudiments. These observations suggest that Hoxa-13 also affected the initial condensation phase of cartilage pattern formation. To investigate this further, we analyzed the involvement of $\operatorname{Hox} a-13$ expression in the differences in cell-to-cell adhesiveness. In mixed culture of endogenous HOXA-13-positive and HOXA-13-negative cells, the positive cells reassociated and were sorted from the negative cells within $24 \mathrm{hr}$ in culture (Fig. 7C,G). In the next experiment, we used cells from the limb buds infected with Hoxa-13 virus, showing mosaic expression of HOXA-13 at stage 20, for the cell-sorting experiment. In these cultures, the HOXA-13positive cells were sorted from nonexpressing cells (Fig. $7 \mathrm{~K}$ ), suggesting that Hoxa-13 controls the differences in the homophilic cell-to-cell adhesiveness of limb mesenchymal cells. At present, we do not know whether this change in cell adhesiveness is really involved in the precartilage bifurcation process. This problem will be answered by isolating molecules that determine observed cell-to-cell adhesiveness.

Initially, we expected that uniform expression of Hoxa-13 would equalize all cell adhesion properties to the Hoxa-13-determined state. This would then result in fusion of the ulna and the ulnale for the fibula and the fibulare in the leg) as a result of equalization of cell adhesiveness. In the present study, no such fusion was observed, with the exception of one example (results not shown). We also analyzed the effects of Hoxa-13 misexpression on the expression patterns of other Hox genes, [i.e., Hoxd-11, Hoxd-12, Hoxd-13, Hoxa-11, and goosecoid, which is expressed in the prospective sacral region and mesenchyme between the tibia and the fibula [Gaunt et al. 1993)]. The expression patterns of these genes were indistinguishable from those during normal development (results not shown). Thus, Hoxa-11 was still expressed in the zeugopod as normal and cells in the Hoxa-11 domain may retain some properties different from those in the autopod, even with Hoxa-13 misexpression. This could be the reason for the absence of the ulna-ulnale fusion in the limb bud despite changes in the cell adhesion properties observed in the more sensitive culture system. Mutually exclusive expression profiles of Hoxa-11 and Hoxa-13 were first found in chicken limb buds (Yokouchi et al. 1991b), and these profiles were then shown to be conserved in those of mice (Haack and Gruss 1993). In normal development, position-specific and mutually exclusive expression of Hox $a$ 11 and $H$ oxa-13 would be required for strict demarcation of the cell adhesion properties between the zeugopod and the autopod through regulation of expression of downstream genes. Interestingly, this mutual exclusion between Hoxa-11 and Hoxa-13 was less obvious in the hindgut (Yokouchi et al. 1995), indicating that the mutual exclusion is tightly linked to specific functions of these Hox genes in limb development. In addition, the distal prevalence rule is not applicable, at least with regard to control of cell adhesiveness.

The question of which molecules affecting cell adhesiveness are under the control of Hoxa-13 remains. Recently, $\mathrm{N}$-cadherin, which is expressed ubiquitously in the mesoderm of developing limb bud and facilitates for homophilic cell adhesion, was reported to be involved in the primary condensation process of cartilage in limb development (Oberlender and Tuan 1994). The neural cell adhesion molecule (NCAM) is also a candidate molecule, as it was shown to be expressed in the perichondrium (Widelitz et al. 1993) and to possess the homeo domain-responsive element in its promoter region by transient transfection analysis (Jones et al. 1992). Unfortunately, neither N-cadherin nor NCAM have restricted expression domains similar to the Hox gene expression 
domains in the limb bud. Many members of the cadherin superfamily of genes have been found in vertebrates $\mathrm{Su}$ zuki et al. 1991). Hence, there may be unknown cadherins or other adhesion molecules expressed in restricted regions of the developing limb buds under the control of Hoxa-13.

\section{Materials and methods}

\section{Construction of recombinant plasmids}

pDS5, a derivative of pDS3 (Iba et al. 1984, 1988), was used for construction of all recombinant viruses. For construction of pDS5, the unique BglII site of pDS3 was converted to an EcoRV site. The SalI fragment, containing the entire viral sequence of this construct, was transferred into the SalI site of pUC9 to produce pDS5. A cDNA clone encoding human placental alkaline phosphatase (PLAP), a kind gift from Dr. S. Udenfriend (Berger et al. 1987), was used as a template for PCR using primers carrying EcoRV sites to produce the entire protein-coding sequence. To construct ALP-pDS5, the PCR products were digested with EcoRV and cloned into EcoRV-digested pDS5. The EcoRI fragment of the Hoxa-4 cDNA clone (Sasaki et al. 1990) was blunt-ended and cloned into EcoRV-digested pDS5, and the resultant construct was designated Hoxa-4-pDS5. For the Hoxa-13 constructs, the sequence covering the translation initiation site was converted to a $B s p H I$ site by PCR. Then, the BspHI-BamHI fragment, which carries the entire protein-coding region and subsequent 3 ' noncoding sequence, was bluntended and cloned into EcoRV-digested pDS5. The BspHI$B a m H I$ fragment was cloned into an IRES-carrying vector (pCITE; Novagen) digested with Ncol and BamHI. Then, the IRES-Hoxa-13 fragment was isolated and cloned into pDS5.

\section{Chick strain and virus production}

All animals were obtained as fertile eggs from the supplier (Nisseiken Ltd.). For injection with A-subgroup retrovirus, specific pathogen-free white Leghorn eggs (line $M$ ), were used. The procedure for virus production was described previously (Iba et al. 1984, 1988; Yoshida et al. 1989). Briefly, pDS5 derivatives were digested completely with Sall and ligated into SalI-digested pREP containing the sequences essential for viral replication to produce an intact proviral DNA structure. The ligated DNAs were introduced into primary cultures of chick embryonic fibroblast cells by the calcium phosphate transfection method. These cells were subdivided into three plates, 2 days after transfection. The culture medium was changed to fresh medium 5-6 days after the transfection, and the recombinant virus was harvested as culture medium $8-10 \mathrm{hr}$ later. The recovered medium was centrifuged at $3000 \mathrm{rpm}$ for $15 \mathrm{~min}$ to remove cellular debris, and aliquots of the supernatant were stored at $-80^{\circ} \mathrm{C}$ until injection.

\section{Microinjection}

Microinjection into chick embryos was performed essentially as described by Morgan et al. (1992). Line M (Nisseiken Ltd.) fertilized eggs were incubated at $38.5^{\circ} \mathrm{C}$ until the desired stage was reached. Eggshells were opened, and a few of drops of Tyrode's solution were added to prevent drying. Virus stock solutions were concentrated 20 - to 25 -fold by volume with Ultrafree $\mathrm{C} 3 \mathrm{KH}$ (Millipore) to give a final titer of $\sim 10^{8}$ infective virus $/ \mathrm{ml}$, just before injection. The concentrated virus solutions were injected into the presumptive right leg or wing field $150-100 \mathrm{nl} /$ injection) at stage 9-10 with microinjector IM-3 (Narishige). Eggs were then sealed and incubated at $38.0^{\circ} \mathrm{C}$ for the appropriate times.

\section{In situ hybridization}

In situ hybridization was performed as described previously (Yokouchi et al. 1991a). Chick embryos were fixed with $4 \%$ paraformaldehyde-PBS and cut into $5-\mu \mathrm{m}$ serial sections on a cryostat. Each section was hybridized with Hoxa-10, Hoxa-11, Hoxa-13, Hoxd-10, Hoxd-11, Hoxd-12, and Hoxd-13 gene-specific antisense RNA probe labeled with digoxigenin. RNA probes were transcribed from genomic clones (Yokouchi et al. 1991b). Probes for PG-Lb and ColX were isolated by PCR, referring to the published sequences. PG-Lb probe was a 950-bp fragment of a partial PG-Lb cDNA (nucleotides 41-991) (Shinomura and Kimata 1992). ColX probe was a 645-bp fragment from the noncollagenous region of al $(\mathrm{X})$ collagen cDNA (nucleotides 1690-2335) (Ninomiya et al. 1986). The PG-H cDNA clone was provided by Dr. Goetinck. Briefly, the 1.3-kb EcoRI-EcoRV fragment from pPG525 (Stirpe and Goetinck 1989) was cloned into pBluescript and used as a template for in vitro RNA synthesis. Specific hybridization was monitored by color reaction through anti-digoxigenin antibody labeled with alkaline phosphatase. Color development was usually carried out for $12-36 \mathrm{hr}$ at room temperature.

\section{Preparation of anti-HOXA-13 antibody}

A DNA fragment carrying the first ATG of Hoxa-13 cDNA to just amino terminal of the homeo domain was prepared by PCR reaction using synthetic oligomers and a Hoxa-13 cDNA clone (M. Yamamoto, Y. Goto, Y. Yokouchi, and A. Kuroiwa, in prep.). The PCR fragment was joined to glutathione $S$-transferase, (GST; Pharmacia pGEX) coding sequence in-frame, then the GST-Hoxa-13 fragment was transferred to the vector carrying the T7 promoter (pET11d; Novagen). The GST-HOXA-13 fusion protein was produced in Escherichia coli BL21(DE3) pLysS by standard methods (Sambrook et al. 1989) and the fusion protein was purified through glutathione-agarose column chromatography (Pharmacia). Immunization and schedule for production of antibody followed standard methods /Coligan et al. 1991). HOXA-13-specific antibody was affinity purified by maltose-binding protein(MBP)/HOXA-13 fusion protein/Sepharose 4B column chromatography. The same DNA fragment used for production of GST-HOXA-13 fusion was inserted into the MBP expression vector (pMal-c; NEB). The MBP-HOXA-13 fusion protein was produced and purified according to the manufacturer's instructions. Specificity of the antibody was determined by whole-mount immunohistochemistry and Western blot analysis.

\section{Whole-mount immunohistochemistry}

Whole-mount immunohistochemistry was performed as described previously (Davis et al. 1991). Embryos were dissected and fixed in methanol/DMSO $(4: 1)$ at $4^{\circ} \mathrm{C}$ overnight followed by incubation with $5 \% \mathrm{H}_{2} \mathrm{O}_{2}$ in methanol/DMSO $(4: 1)$ for 5 hr. The embryos were rehydrated through a methanol/PBS series and blocked in PBSMT $(2 \%$ skimmed milk, $0.5 \%$ Triton $\mathrm{X}-100$ in PBS) for $2 \mathrm{hr}$ at $4^{\circ} \mathrm{C}$. Embryos were then incubated with $1: 12,000$ diluted anti-HOXA-13 rabbit $\operatorname{IgG}(145 \mu \mathrm{g} / \mathrm{ml})$ in PBSMT for $16 \mathrm{hr}$ at $4^{\circ} \mathrm{C}$, followed by washing in PBSMT for a total of $5 \mathrm{hr}$. Subsequently, embryos were incubated in 1:500 diluted anti-rabbit goat IgG-labeled with HRP (Zymed) in PBSMT for $16 \mathrm{hr}$ at $4^{\circ} \mathrm{C}$, then washed with PBSMT for a total of 5 hr and rinsed with PBT $(0.5 \%$ Triton X-100 in PBS) for 5 min. Then the embryos were incubated in the detection solution $[0.3$ $\mathrm{mg} / \mathrm{ml}$ of diaminobenzidine (DAB), $0.5 \% \mathrm{NiCl}_{2}$ in PBT] for 30 min, subsequently, $3 \% \mathrm{H}_{2} \mathrm{O}_{2}$ was added (final concentration, $0.015 \%$ ). Black signal was detected within $1 \mathrm{~min}$. Color development was stopped by rinsing with PBS. 


\section{Cartilage staining and paraffin sections}

Embryos were dissected at 6 or 8 days after injection (total, 7.5 or 9.5 days of incubation) and fixed overnight in $10 \%$ formaldehyde. The embryos were then immersed in $70 \%$ ethanol $/ 1 \%$ $\mathrm{HCl}$ for $3 \mathrm{hr}$, stained with $0.1 \%$ Alcian blue $/ 70 \%$ ethanol $/ 1 \%$ $\mathrm{HCl}$ for $3 \mathrm{hr}$, and washed with $70 \%$ ethanol $/ 1 \% \mathrm{HCl}$ overnight. Then, they were dehydrated with ethanol and cleared with methyl salicylate. Paraffin sections were prepared by the standard protocol (Sambrook et al. 1989) and stained with hematoxylin and eosin.

\section{Primary cell culture of chick limb mesoderm}

Primary cell culture of chick limb buds was performed as described previously (Ide et al. 1994). Briefly, chick embryos were harvested into cold Tyrode's solution and limb buds were dissected out. The limb buds were washed with fresh cold Tyrode's solution, collected, and treated with $0.7 \%$ trypsin/Tyrodes for $40 \mathrm{~min}$ at $4^{\circ} \mathrm{C}$. The limb buds were transferred to cold Tyrode solution and the ectoderm was removed manually with fine tungsten needles. Subsequently, the limb buds were transferred into calcium, magnesium-free (CMF)-Tyrode's solution and incubated at $37^{\circ} \mathrm{C}$ for $40 \mathrm{~min}$. This solution was then replaced with $1 \%$ FCS/F12, and mesodermal tissues were suspended into single cells by pipetting. Cell numbers were determined and cells were seeded into penicillin cups in 24-well plates (Coster) to a final density of $2 \times 10^{5}$ cells/well. The penicillin cups were removed $4 \mathrm{hr}$ after incubation and filled with $2 \mathrm{ml}$ of $1 \%$ FCS/F12.

\section{Immunohistochemical analysis of cell cultures}

Chick primary cell cultures were rinsed with cold PBS and fixed with $2 \%$ paraformaldehyde, $0.5 \%$ Triton X-100/PBS at $4{ }^{\circ} \mathrm{C}$ for 2 hr. Cells were washed with cold PBS and incubated with 1:400 diluted anti-chick monoclonal antibody A223 and 1:400 diluted anti-HOXA-13 rabbit polyclonal antibody at $4^{\circ} \mathrm{C}$ overnight. Then, samples were washed with cold PBS and incubated with FITC-conjugated anti-mouse IgG (1:300 diluted; Cappel) and Texas Red-conjugated anti-rabbit IgG (1:300 diluted; Vector) for $2 \mathrm{hr}$. Samples were washed and stained with DAPI to determine total cell number and sealed with glycerol; photomicrographs were taken under UV illumination.

\section{Acknowledgments}

We are grateful to Dr. S. Udenfriend (Roche Institute) and Dr. Goetinck (Massachusetts General Hospital) for providing us the cDNA clones encoding human placental alkaline phosphatase and chicken proteogycan $\mathrm{H}$, respectively. This work was supported by grants-in-aid from the Ministry of Education, Science and Culture of Japan to Y.Y. and A.K.

The publication costs of this article were defrayed in part by payment of page charges. This article must therefore be hereby marked "advertisement" in accordance with 18 USC section 1734 solely to indicate this fact.

\section{References}

Balling, R., G. Mutter, P. Gruss, and M. Kessel. 1989. Craniofacial abnormalities induced by ectopic expression of the homeobox gene Hox-1.1 in transgenic mice. Cell 58: 337-347.

Berger, J., E. Garattini, J.-C. Hua, and S. Udenfriend. 1987. Cloning and sequencing of human intestinal alkaline phosphatase cDNA. Proc. Natl. Acad. Sci. 84: 695-698.

Burke, A.C., C.E. Nelson, B.A. Morgan, and C. Tabin. 1995. Hox genes and the evolution of vertebrate axial morphology. Development 121: 333-346.

Coligan, J.E., A.M. Kruisbeek, D.H Margulies, E.M. Shevach, and W. Stober. 1991. Current protocols in immunology. John
Wiley \& Sons, New York.

Davis, A.P. and M.R. Capecchi. 1994. Axial homeosis and appendicular skeleton defects in mice with a targeted disruption of hoxd-11. Development. 120: 2187-2198.

Davis, A.P., D.P. Witte, H.M. Hsieh-Li, S.S. Potter, and M.R. Capecchi. 1995. Absence of radius and ulna in mice lacking hoxa-11 and hoxd-11. Nature. 375: 791-795.

Davis, C.A., D.P. Homyard, K.J. Millen, and A.L. Joyner. 1991. Examining pattern formation in mouse, chicken and frog with an En-specific antiserum. Development 111: 287-298.

Dollé, P., J.-C. Izpisúa-Belmonte, H. Falkenstein, A. Renucci, and D. Duboule. 1989. Coordinate expression of the murine Hox-5 complex homeobox-containing genes during limb pattern formation. Nature 342: 767-772.

Dollé, P., A. Dierich, M. LeMeur, T. Schimmang, B. Schuhbaur, P. Chambon, and D. Duboule. 1993. Disruption of the Hoxd13 gene induces localized heterochrony leading to mice with neotenic limbs. Cell 75: 431-441.

Duboule, D. 1994. How to make a limb? Science 266: 575-576.

Duboule, D. and G. Morata. 1994. Colinearity and functional hierarchy among genes of the homeotic complexes. Trends Genet. 10: 358-364.

Favier, B., M. Le Meur, P. Chambon, and P. Dollé. 1995. Axial skeleton homeosis and forelimb malformations in Hoxd-11 mutant mice. Proc. Natl. Acad. Sci. 92: 310-314.

Fell, H.B. 1925. The histogenesis of cartilage and bone in the long bones of the embryonic fowl. I. Morphl. Physiol. 40: $417-459$.

Gaunt, S.J., M. Blum, and E.M. De Robertis. 1993. Expression of the mouse goosecoid gene during mid-embryogenesis may mark mesenchymal cell lineages in the developing head, limbs and body wall. Development 117: 769-778.

Haack, H. and P. Gruss. 1993. The establishment of murine Hox-1 expression domains during patterning of the limb. Dev. Biol. 157: 410-422.

Hamburger, V. and H.L. Hamilton. 1951. A series of normal stages in the development of chick embryo. I. Morphol. 88: 49-92.

Hinchliffe, J.R. and D.R. Johnson. 1980. The development of the vertebrate limb. Oxford Science Publications, Clarendon Press, Oxford, UK.

Iba, H., T. Takeya, F.R. Cross, T. Hanafusa, and H. Hanafusa. 1984. Rous sarcoma virus variants that carry the cellular src gene instead of the viral src gene cannot transform chicken embryo fibroblasts. Proc. Natl. Acad. Sci. 81: 4424-4428.

Iba, H., Y. Shindo, H. Nishina, and T. Yoshida. 1988. Transforming potential and growth stimulating activity of the $\mathrm{v}$-fos and c-fos genes carried by avian retrovirus vectors. Oncogene Res. 2: 121-133.

Ide, H., N. Wada, and K. Uchiyama. 1994. Sorting out of cells from different parts and stages of the chick limb bud. Dev. Biol. 162: 71-76.

Izpisúa-Belmonte, I.-C., C. Tickle, P. Dollé, L. Wolpert, and D. Duboule. 1991. Expression of the homeobox Hox-4 genes and the specification of position in chick wing development. Nature 350: 585-631.

Jegalian, B.G. and E.M. De Robertis. 1992. Homeotic transformations in the mouse induced by overexpression of a human Hox3.3 transgene. Cell 71: 901-910.

Jones, F.S., E.A. Prediger, D.A. Bittner, and E.M. De Robertis. 1992. Cell adhesion molecules as targets for Hox genes: Neural cell adhesion molecule promoter activity is modulated by cotransfection with Hox-2.5 and -2.4. Proc. Natl. Acad. 89: 2086-2090.

Krumlauf, R. 1994. Hox genes in vertebrate development. Cell 78: 191-201. 
Leonard, C.M., H.M. Fuld, D.A. Frenz, S.A. Downie, J. Massague, and S.A. Newman. 1991. Role of transforming growth factor- $\beta$ in chondrogenic pattern formation in the embryonic limb: Stimulation of mesenchymal condensation and fibronectin gene expression by exogenous TGF- $\beta$ and evidence for endogenous TGF- $\beta$-like activity. Dev. Biol. 145: 99-109.

Linsenmayer, T.F., Q. Chen, E. Gibney, M.K. Gordon, J.K. Marchant, R. Mayne, and T.M. Schmid. 1991. Collagen types IX and $\mathrm{X}$ in the developing chick tibiotarsus: Analyses of mRNA and proteins. Development 111: 191-196.

Lufkin, T., M. Mark, C.P. Hart, P. Dollé, M. LeMeur, and P. Chambon. 1992. Homeotic transformation of the occipital bones of the skull by ectopic expression of a homeobox gene. Nature 359: 835-841.

Lyons, K.M., R.W. Pelton, and B.L.M. Hogan. 1990. Organogenesis and pattern formation in the mouse: RNA distribution patterns suggest a role for Bone Morphogenetic Protein2A(BMP-2A). Development 109: 833-844.

McGinnis, W. and R. Krumlauf. 1992. Homeobox genes and axial patterning. Cell 68: 283-302.

Millan, F.A., F. Denhez, P. Kondaiah, and R.J. Akhurst. 1991. Embryonic gene expression patterns of TGF $\beta 1, \beta 2, \beta 3$ suggest different developmental functions in vivo. Development 111: 131-144.

Morgan, B.A., J.-C. Izpisúa-Belmonte, D. Duboule, and C.J. Tabin. 1992. Targeted misexpression of Hox-4.6 in the avian limb bud causes apparent homeotic transformations. Nature 358: $236-239$.

Ninomiya, Y., M. Gordon, M. Van Der Rest, T. Schmid, T.F. Linsenmayer, and B.R. Olsen. 1986. The developmentally regulated type $\mathrm{X}$ collagen gene contains a long open reading frame without introns. I. Biol. Chem. 261: 5041-5050.

Niswander, L., C. Tickle, A. Vogel, I. Booth, and G.R. Martin. 1993. FGF-4 replaces the apical ectodermal ridge and directs outgrowth and patterning of the limb. Cell 75: 579-587.

Niswander, L., S. Jeffrey, G. Martin, and C. Tickle. 1994. A positive feedback loop coordinates growth and patterning in the vertebrate limb. Nature 371: 609-612.

Nohno, T., S. Noji, E. Koyama, K. Ohyama, F. Myokai, A. Kuroiwa, T. Saito, and S. Taniguchi. 1991. Involvement of the Chox-4 chicken homeobox genes in determination of anteroposterior axial polarity during limb development. Cell 64: 1197-1205.

Oberlender, S.A. and R.S. Tuan. 1994. Expression and functional involvement of $\mathrm{N}$-cadherin in embryonic limb chondrogenesis. Development 120: 177-187.

Oohira, A., K. Kimata, S. Suzuki, K. Takata, I. Suzuki, and M. Hoshino. 1974. A correlation between synthetic activities for matrix macromolecules and specific stages of cytodifferentiation in developing cartilage. J. Biol. Chem. 249: 1637-1645.

Oster, G.F., N. Shubin, J.D. Murray, and P. Alberch. 1988. Evolution and morphogenetic rules: The shape of the vertebrate limb in ontogeny and phylogeny. Evolution 42: 862-884.

Parr, B.A. and A.P. McMahon. 1995. Dorsalizing signal Wnt-7a required for normal polarity of $\mathrm{D}-\mathrm{V}$ and $\mathrm{A}-\mathrm{P}$ axes of mouse limb. Nature 374: 350-353.

Pollock, R.A., G. Jay, and C.J. Bieberich. 1992. Altering the boundaries of Hox3.1 expression: Evidence for antipodal gene regulation. Cell 71: 911-923.

Rancourt, D.E., T. Tsuzuki, and R. Capecchi. 1995. Genetic interaction between hoxb-5 and hoxb-6 is revealed by nonallelic noncomplementation. Genes \& Dev. 9: 108-122.

Riddle, R.D., R.L. Johnson, E. Laufer, and C. Tabin. 1993. Sonic hedgehog mediates the polarizing activity of the ZPA. Cell 75: 1401-1416.
Sambrook, J., E.F. Fritsch, and T. Maniatis. 1989. Molecular cloning: A laboratory manual. Cold Spring Harbor Laboratory Press, Cold Spring Harbor, New York.

Sasaki, H., E. Yokoyama, and A. Kuroiwa. 1990. Specific DNA binding of the two chicken Deformed family homeodomain proteins, Chox-1.4 and Chox-a. Nucleic Acid Res. 18: 17391747.

Shinomura, T. and K. Kimata. 1992. Proteoglycan-Lb, a small dermatan sulfate proteoglycan expressed in embryonic chick epiphyseal cartilage, is structurally related to osteoinductive factor. J. Biol. Chem. 267: 1265-1270.

Shinomura, T., K. Kimata, Y. Oike, N. Maeda, S. Yano, and S. Suzuki. 1984. Appearance of distinct types of proteoglycan in a well-defined temporal and spatial pattern during early cartilage formation in the chick limb. Dev. Biol. 103: 211-220.

Small, K.M. and S.S. Potter. 1993. Homeotic transformations and limb defects in Hox All mutant mice. Genes \& Dev. 7: 2318-2328.

Sordino, P., F. van der Hoeven, and D. Duboule. 1995. Hox gene expression in teleost fins and the origin of vertebrate digits. Nature 375: 678-681.

Stirpe, N.S. and P.F. Goetinck. 1989. Gene regulation during cartilage differentiation: Temporal and spatial expression of link protein and cartilage matrix protein in the developing limb. Development 107: 23-33.

Stocum, D.L., R.M. Davis, M. Leger, and H.E. Conrad. 1979. Development of the tibiotarsus in the chick embryo: Biosynthetic activities of histologically distinct regions. I. Embryol. Exp. Morphol. 54: 155-170.

Storm, E.E., T.V. Huynh, N.G. Copeland, N.A. Jenkins, D.M. Kingsley, and S.-J. Lee. 1994. Limb alterations in brachypodism mice due to mutations in a new member of the TGF $\beta$ superfamily. Nature 368: 639-643.

Summerbell, D. 1976. A descriptive study of the rate of elongation and differentiation of the skeleton of the developing chick wing. I. Embryol. Exp. Morphol. 35: 241-260.

Summerbell, D., J.H. Lewis, and L. Wolpert. 1973. Positional information in chick limb morphogenesis. Nature 244: 492-496.

Suzuki, S., K. Sano, and H. Tanihara. 1991. Diversity of the cadherin family: Evidence for eight new cadherins in nervous tissue. Cell Regul. 2: 261-270.

Tabin, C.J. 1992. Why we have (only) five fingers per hand: Hox genes and the evolution of paired limbs. Development 116: $289-296$.

Widelitz, R.B., T.X. Jiang, B.A. Murray, and C.M. Chuong. 1993. Adhesion molecules in skeletogenesis: II. Neural adhesion molecules mediate precartilagenous mesenchymal condensations and enhance chondrogenesis. I. Cell Physiol. 156: 399-411.

Wolpert, L. 1990. Signals in limb development: STOP, GO, Stay and POSITION. I. Cell Sci. (Suppl.) 13: 199-208.

Yokouchi, Y., K. Ohsugi, H. Sasaki, and A. Kuroiwa. 1991 la. Chicken homeobox gene Msx-1: Structure, expression in limb buds and effect of retinoic acid. Development 113: $431-444$.

Yokouchi, Y., H. Sasaki, and A. Kuroiwa. 1991b. Homeobox gene expression correlated with the bifurcation process of limb cartilage development. Nature 353: 443-445.

Yokouchi, Y., I. Sakiyama, and A. Kuroiwa. 1995. Coordinated expression of $A b d-B$ subfamily genes of $\operatorname{Hox} A$ cluster in the developing digestive tract of chick embryo. Dev. Biol. 169: 76-89.

Yoshida, T., Y. Shindo, K. Ohta, and H. Iba. 1989. Identification of a small region of the $v$-fos gene product that is sufficient for transforming potential and growth-stimulating activity. Oncogene Res. 5: 79-89. 


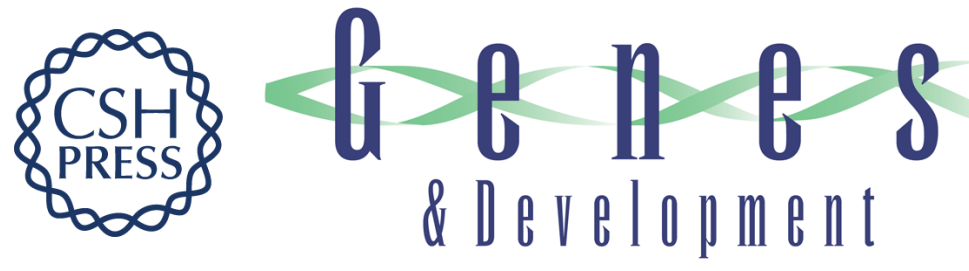

\section{Misexpression of Hoxa-13 induces cartilage homeotic transformation and changes cell adhesiveness in chick limb buds.}

Y Yokouchi, S Nakazato, M Yamamoto, et al.

Genes Dev. 1995, 9:

Access the most recent version at doi:10.1101/gad.9.20.2509

References This article cites 58 articles, 21 of which can be accessed free at:

http://genesdev.cshlp.org/content/9/20/2509.full.html\#ref-list-1

License

Email Alerting

Service

Receive free email alerts when new articles cite this article - sign up in the box at the top right corner of the article or click here.

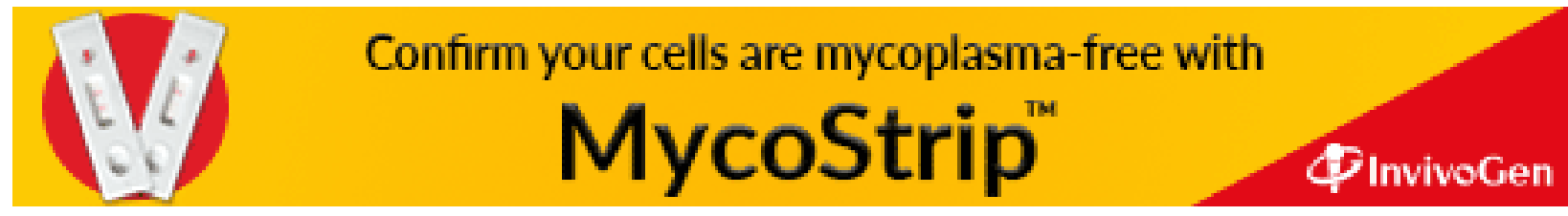

